\title{
PAN AFRICANIST IDEAS, ISSUES AND CHALLENGES
}

\author{
Oladipo, Folusho Adewumi \\ Department of History and International Studies \\ College of Liberal Studies, Bowen University, Iwo, Osun State, Nigeria
}

\begin{abstract}
The growing awareness and appendage of "black is beautiful" is a not a contemporary phenomenon but a contemporaneous wave deeply rooted in one of the most elusive coinage. Africans from time immemorial had in its own right and way developed and advanced the environment in which he lived, taking advantage of all nature provided. It was a one human entity whose development and civilisation was not in any way inferior to western civilisations displaying the earliest techniques of environmental subjugation. Africa flourished immensely to the attraction of all races in agriculture, arts and crafts, and state administration with copious proofs of Western Sudanese Empires, the Dahomey Kingdom, Guinea forest states of Oyo and Benin Empires, infamous Saifawa dynasty which began in the $8^{\text {th }}$ century and lasted a thousand years. In sharing the economic prosperity by projected by Africa, the Arabs bridges the hitherto communication barrier of the Sahara desert to reach the prosperous people.

The hitherto calmness was upset by the Europeans notably the Portuguese early comers who aimed at breaking the monopoly of the Arabs over West African trade; whose pursuit soon subtly metamorphosed into an ungodly obnoxious trade in sweat and blood which altered the dignity and destroyed the hitherto peaceful civilisation and development and a fairly self sufficient Africa. It placed the black race on the pedestal of inconsequential and worthless race ... which none ever discovered any symptoms of ingenuity...
\end{abstract}

Though a plethoral of literature exist on Pan Africanism, there is the paucity of engagement of Pan African ideas in the explanation of solutions to African problems. This paper adopts analytical and descriptive methods of analysis through secondary sources.

Key words: Pan Africanism, Diaspora, blacks, dignity, African development.

\section{INTRODUCTION}

The increasing wave of appreciating the uniqueness of the black concept is fast gaining momentum across all sectors of life, even to its adoption in the brewing and advertisement of 'made of black, made of more' drink slogan in the appealing to a wider range of African consumers. The appreciation flows from the continuous and incessant efforts of blacks both home and in diaspora in showcasing the beauty, resilience, and achievement spirit of the African man, standing him out in all sectors and walks of life. This increasing acceptance of the beauty of the blacks is firmly rooted in one of the most contested concept of casting aside imposed external subjugation and regaining the trampled and lost dignity through the adoption of "Africanness" and developing in the African way.

Legum,(1965) is of the summation that depiction of the distinctiveness of the blacks emanated from the physical dispossession of the black man through slavery, the social, economic, political and mental slavery through colonialism which lead to the loss of homelands and has ultimately led to his enslavement, dependence and subjugation. In spite of the end of the $1^{\text {st }}$ and $2^{\text {nd }}$ phases of slavery according to Pius Okigbo, the independence demanded and conceded to the pioneer African leaders was one that was superficial and directed to the changing of administrative heads and not colonial economic entrenchments and bases that ensured the sustenance of African countries on the developed economies.

Duodu, (2011) opined that the achievement of the African personality with extolled dignity, promotion and protection of the interest of all subjects claiming African descent, wholly or in part ... especially Africa has not been achieved due to the insidious colonial structures and internal realities put in place to frustrate Africa's efforts at breaking loose from sustained dependence and relationship which is the $3^{\text {rd }}$ phase of slavery.

This paper examines the oneness of the African human entity, the subtlety of two insidious machinations of the transformation from a balanced trade to an obnoxious unjustified trade in Africa blood and sweat which laid the foundation for the 
discrimination, , disrespect, unfair treatment and a fight for the lost and trampled dignity of the blacks, expanded Pan Africanist ideas during colonialism, divergent reactions from blacks and afrocentric scholars, challenges of the achievement of a united Africa, and an appraisal of panaceas put in place in the addressing of Africa's challenges.

\section{CONCEPTUAL CLARIFICATION}

Pan Africanism is a closely contested concept with divergent and differing definitions. However, in spite of the ranging perspectives, according to Toure (1982), the definitions are all strongly anchored on wanting to be determining and decisive in the search for the wellbeing of African peoples, continuation of social promotion, liberation of Africa from nature's constraint, giving him permanently ever increasing well being and fulfilment. To the American society of African culture cited by Esedebe (1970) it is a self government or independence by African nations south of the Sahara; avoidance of conflicts, territorial and otherwise, in Africa. To Apiah (2012) It is a political project calling for the unification of all Africans into a single African State, to which those in the African Diaspora can return. For the purposes of this work, the definition of Legum (1965) which opines Pan Africanism as the casting aside by Africans of subservience to foreign masters in all forms and the confident assertion that African interests are paramount ... in the bringing about at the earliest possible time the industrial and spiritual emancipation of the Negro people would be adopted.

How Africa Developed before the Coming of the Europeans up to the $15^{\text {th }}$ Century

According to Casely-Hayford, $\mathbf{J}$ in Rodney,W.(1972), Africa from time immemorial had been a one human entity, developed and advanced environment with striking and noble earliest techniques of environmental subjugation, flourishing agriculture, arts and crafts which heralded its fairly self sufficient existence, a developed people, having our own well structured institutions, having its own ideas of government and state administration In North Africa, Egypt rose as a world power over 3000BC with striking degrees of technological advancement and dexterity employed in the building of pyramids and Pharaoh tombs which have been classified as one of the wonders of the world. In attestation to the high pedigree of the architectural structures and designs, these edifices are in existence and have become tourist and revenue generation sites for the Egyptian economy. In the domestication of its arid environment, and ensuring a self sufficient agricultural practice which would ensure a constant and all year round food supply, Egypt developed an indigenous method of irrigation from the River Nile, powered by the wind mill. In developing a timely and timeless method of communication, the hieroglyphics method of writing and evidently present in Egyptian museums. With its close proximity to Europe, North Africa did not love in isolation as it was the bridge through which the economic development of West Africa as displayed by the high quality of African products were publicised to the world such the infamous misnamed Morroccan leather tied and tanned by Hausas in present day Nigeria and Mandingas in Mali.

Within the Bilad-al-Sudan were the well popularised Sudanese empires which were the earliest forms organised state administration such as Ghana, Mali, Songhai empires, the Saifawa Dynasty of the Kanem-Bornu Empires, Guinea forest states of Oyo and Benin among others. With its favourable geographical location such as wide expanse of land, natural resources, these advantages were deployed to the advantages of the various West African states which were built on agrarian economies (due to the differing topographies, goods from one zone found its way to others particularly through long distance trades with differing currency tenders ranging from barters, iron bars, manilas, cowries among others) and trade particularly with the Arabs through North Africa that resulted in the introduction and spread of Islam in West Africa and the concomitant intellectual, architectural, social, educational and economic effects of Islam in West Africa. Islam in West Africa attracted scholars such as Ibn Khaldun, Al-Bakri, Mahmud Al-Fattash among others who deployed their intellectual wealth in contributing to the educational development of West Africa through the establishment of one of the earliest Universities of Africa in Timbuktu as early as the $14^{\text {th }}$ century. Due to the intellectual revolution in West Africa, to Rodney (1972), Surgical operations were first performed in West Africa, centuries before its knowledge reached Europe Trade in gold, salt, spices in notable commercial centres such as Gao, Jenne, Timbuktu, taxes exerted on good and security levies paid for safe passages and operation generated huge revenues for state administration.

Eastern Africa was also not left out in the wave of development as Rodney (1972) argued that the productive base and the political superstructure can be ascertained to have developed appreciably before Africa was drawn in contact with Europe. The construction of architectural structures which flourished in Zimbabwe (Zambesi and Limpopo cultures) such as the great Zimbabwe wall was 300 feet long, 220 feet broad, 30 feet high and 20 feet thick in bricks to Rodney (1972) was an attestation to the ingenuity of the East African man with Arts and crafts receiving tremendous patronages as 
those who worked on gold produced ornaments with tremendous skill lightness of touch.

The differing African geographical zones were not deterrence factors as Africa was a one human entity characterised by free movement of persons and goods as evident from distance trades; clothes made in Kano were found on Arguin highland near Senegal. Though differing currencies, they were easily convertible to others. The relationship between Africans were relatively peaceful evident from intermarriages, shared religious rites and ceremonies secured inter community passages. Conflict a normal occurrence in human relationships spiced the relationships such as inter communal clashes, territorial wars among others. These conflicts did not hamper development as various conflict management methods were put in place to mend brolen or strained relationships owing to the interdependency of the African communities.

Traditional African religion played an indispensable role in the development of the precolonial African states as its philosophies were anchored on sustainable development which perceived the existence of Africa as a continuum which extended from the ancestors even to the generations unborn. Hence, power was held in trust.

Trade between West Africa and the wider world particularly West African and Arabian trade through the Sahara popularised the exceeding wealth, prosperity and blossoming econo,ies of West Africa which set the precedence for the monopoly and middle man role assumed by the Arabs on West African goods. This position of the Arabs had increment effects on the prices of goods such as gold, leathers, spices, salt transacted with the Europeans. The ultimate desire by Europeans to breaking the monopoly and having a direct contact with West Africans through the navigation of the Atlantic among other motives led to the arrival of the Portuguese in the mid $15^{\text {th }}$ century in Benin.

The arrival of Europeans marked a watershed in the history of West Africa as there was a dynamic shift from the Trans Saharan trade to the Atlantic trade. In exchange for African gods, irrelevant and inconsequential barters were made that had no positive effects on the development of the African economies such as Ostrich feathers, guns, gun powders, mirrors, clothes which laid the foundation for an unbalanced system of trade.

\section{THE SLAVE TRADE}

The establishment of plantations in the new world such as the Americas, Canada etc by European countries and the paucity of labour on these plantations, advice of Barthlomew Las Casas among other factors changed the nature of trade and relationship between Africa and the Europeans. The hitherto transactions of natural produces were replaced by trade in African sweat and blood through the machination of both African and European actors which subtly began with coastal kidnappings by Europeans. On the strength of the inability of kidnappings to produce the required labour, Africans were cajoled and coerced into a working relationship in the sale of their fellow Africans into slavery in lands beyond the Atlantic. The desperation, covetousness and gullibility of the African man unleashed cruelty on his fellow man as the unimaginable task of forceful recruitment of labour was conducted through incessant raids of settlements with fire, forceful adoption and kidnapping of able bodied men and women, conscious and deliberate war outbreak. Able bodied men between the ages of 15 and 35 were carted away like prisoners of war, the absence of coasts in the hinter land prompted the marching of slaves to the coasts such as Gwetto, Badagry, Cape coast hundreds of kilometres in distance in humiliating manners with chains tied each to prevent escape and ensure compliance. Many from the cruelty of the journey passed on in transit to the coast with nostalgia and neglect from Africans to Africans. As argued by Curtin (1969), the forcefully uprooted Africans estimating 9,566 000 slaves were imported as commodities into the Americas and other parts of the Atlantic basin from 1451-1870 through the Atlantic, like closely and tightly packed sardines in baracons.

In line with Anene (1966) summation, the forceful eviction of Africa's productive population that had hitherto contributed tremendously to the building of their various states and empires through economic activities launched Africa into epileptic and nosediving economies, undermining all elements of civilizing growth in Africa.

The inhumanity of Africans to Africans gave Europeans the free hand and liberty to unleash cruelty and maltreatment on African slaves both on transit, arrival and engagement on European plantations in the new world. The horrendous working conditions such as the piercing of slaves mouth and padlocked as anti theft mechanisms, castration, denied rights, maltreatment further demoralised and shattered the crumbs of dignity that remained in the African man.

To Davidson (1980), the obnoxious trade in African blood marked a dynamic shift in the perception of the black man by the Europeans as it stained, ruined much of the fabric of African society while permitting nothing better to replace it. The trade implanted arrogance, Caucasian perception and racial superiority of the white man over the black skinned, consequently explaining the disdain, intellectual and racial arrogance assumed by Europeans subsequently. 
The industrial revolution in Europe led by England rendered obsolete the services of the African slaves and created insatiable urge for the obtaining of raw materials for their industries which were in abundance in Africa. The pursuit of this chief aim, achievable under peaceful atmosphere prompted Britain to leading the slave trade abolition crusades from 1807. The abolition of slave trade in the latter part of the $19^{\text {th }}$ century marked the liberation from the $1^{\text {st }}$ phase of slavery.

\section{AFRICA AND LEGITIMATE TRADE}

From 1807, industrial revolution soon spread to other European countries who also became interested in the bountiful resources Africa posed to offer. The drive among European states for easy access to raw materials such as palm-oil, Shea butter resulted in an unprecedented jostling and competition among them. The desperation in the securing of raw materials and desire to have a direct access to the African hinterland pitched the Europeans against African kings and middle men that hitherto being independent merchants, created a monopoly and intermediaries between the hinter lands and the Europeans at the Coast. The feverishness in the acquisition of spheres of influence can be described as the scramble for Africa.

Collaborating Hobson (1975) position, the shift in the production level in Europe spurred the expansion of economic motives to accommodating the desire to also secure a large market for their finished goods in the late $19^{\text {th }}$ century. Hobson argued that the new imperialism of the late $19^{\text {th }}$ century resulted from over production in Europe from surplus capital and under consumption. On the basis of these exponential needs, European countries were constrained to pursue a policy of political expansions. Lenin (1939) opines that imperialism was an inevitable outcome of the dynamics and crisis of capitalist production in Europe and the acquisition of territories overseas and colonisation of such were strategies to achieving spheres of formal political influences which in turn facilitated exploitation of territories. Attempts were made by African kings and middle men such as Nana Olomu of Itsekiri, Jaja of Opobo among other kings to control the local markets and dictate the terms of trade which resulted in clashes over jurisdiction and control of territories and areas of operation among African kings consequently causing deliberate interrupted supply of agricultural produce. In response to the 'unruly' activities of the African men, invites were made to European home governments to embark on aggressive occupation of African territories and imposition of European law and order to deal with difficult African kings and break the monopoly wielded to regulate trading activities. The intervention of European governments led to the granting of charters and right of operations to several companies such as the Royal Niger Company, United African Company, John Holt Conglomerates, Liverpool brothers among others.

European countries succeeded in avoiding conflicts among themselves largely through diplomatic efforts and treaties such as the Otto Von Bismarck inspired Berlin 1884-1885 international conference which laid the foundation and basis for the partition of Africa subsequently. After the conference, a few bilateral agreements were signed which included the Anglo-German treaties of 1890 and 1893, Anglo-Italian treaty of 1891 recognised the upper Nile as a British Colony. In West Africa, the most important agreements were the Sai-Barruwa agreement of 1890 and the Niger Convention of 1898 which achieved the partitioning of West Africa by France and Britain.

From 1900, the various European governments assumed a direct administration of their territories, withdrawing administrative charters granted European merchants.

\section{THE FOUNDATIONS OF PAN AFRICANISM}

As a concomitant effect of Slave trade, disdain, discrimination and disregard for the black skinned peoples assumed an intellectual and racial arrogance in Europeans who saw themselves as agents of development and saviour of the African continent from "barbarous gyrations in picturesque". This feeling of superiority according to Hume in Duodu (2011) watered down the African continent as the uncivilised nation, bereft of eminent individuals either in action or speculation, absence of indigenous manufactures, no arts or science and best regarded as monkeys with no symptoms of ingenuity. The black man everywhere in the world was treated in this manner. The absence of unity among the black skinned race both home and abroad to fight and address the issues bedevilling them subjected them to unprecedented racial discrimination. The denial and discrimination against Edward Wilmot Blyden (son of a black slave in Diaspora) from gaining admission into a theological college in the United States of America on the basis of his race laid the foundation for the political, intellectual and racial movement for the blacks for the redemption of the lost, down trodden African personality according to Duodu (2011) began from Blyden. In protest to the underserved denial, Blyden engaged the European apologists and the maltreated Africans both home and abroad intellectually and intelligently through hos writings such as "A voice from Bleeding Africa,(1856), The Negro in Ancient 
History(18699, The West African University(1872)" boosting the morale, displacing the inferiority of Africans to Europeans and restoring the sense of dignity of the African man through the reminder of his great exploits before the cancerous contact with the Europeans making clarion calls to Africans both home and abroad to converging uniting and advancing by methods of his own, possessing power distinct from that of the European showing Africa is able to go alone, to carve out its own way, not satisfied that in the continent European influence shapes polities, makes our laws, rules. Legum (1965) argues that If Africa is to make an independent nation, a strong nation, she must listen to the songs of our unsophisticated brethren as they sing of their history, tell of their traditions, wonderful and mysterious events of their tribal or national life of the achievements we call superstition in displacing the jaundiced erroneous perception of Africa and on the platform through which Africa will be for Africans and a home of freedom.

In engaging the European populace, Blyden ejected the inferiority, evil, terrifying and primitive narratives about the black man, arguing and projecting the worthy history and culture of Africans and Africa, emphasising the providential assignment of different races, beauty, and the pride in the power of blacks because Our God is black according to Armattoe R in Legum (1965);

\section{Black of eternal blackness}

\section{With large voluptuous lips Mutted hair and brown} eyes

The trail blazed by Wilmot set the path and course bon which subsequent African patriots such as W.E.B DuBois, Sylvester Williams, Marcus Garvey among others drew inspiration and built their convictions.

\section{COLONIALISM IN AFRICA AND PAN AFRICAN MOVES}

Although colonialism did not last more than 80 years in Africa, it was an extremely important episode in the faceted long history of the continent with clear marked changes in the political, economic and social history and development of the continent. Colonialism was the imposition of European rule over African communities who were subjugated between 1880 and 1914 by the power of the Maxim gun. Africans were to be both enlisted and directed by Europeans for purposes defined not by Africans but by Europeans for the benefit of mankind and Africans themselves.

The purposes of colonial administration were firmly built on economic bases which integrated African economies into the international trade on an unbalanced basis; Such as the securing of free access to raw materials from colonies, and a large market for their finished goods characterised by the stimulation of production of cash crops such as palm produce, cotton, rubber, coffee, timber and in East Africa Sisal hemp, the encouragement of consumption and importation of European manufactured gods and especially to ensure that the trade of the colony was conducted solely with the metropolitan state. The economic motives were the substructures on which the political administrations of colonies were anchored.

The imposed government in the pursuit of its economic aims excluded African elites from administration for the adoption of traditional institution officials under the false excuse of scrupulous respect for the beliefs and habits and traditions of the conquered peoples. The exclusion was to achieve easy manipulation of the people through traditional offices. The imposed gruesome alien rule $\mathrm{n}$ Africans received intellectual and political reactions from afro centric scholars and patriots emphasising the need and necessity of Africa's unity and decisively fight and dislodge in all its across the continent.

In Legum (1965) position, Edward Wilmot Blyden's sown seeds of the unity of Africans to fight the physical dispossession of the black man through slavery and the social, economic, political and mental slavery through colonialism which has led to a loss of homeland and have achieved enslavement, persecution, inferiority, discrimination of the black skinned man inspired Sylvester Williams a Trinidad lawyer to continue the challenge and make concrete steps to the achievement of Africa's unity. He formed the first African Association in 1900 to promote and protect the interests of all subjects claiming African descent, wholly or in part in British colonies and other places especially Africa. Williams saw the need for all people of the African descent to vocally and intellectually address the issues that faced the African descent. The addressing of the problems of the African descent inspired the first convergence of blacks across the world at the $1^{\text {st }}$ Pan African Conference in 1900, held in London and sponsored by Williams. Sherwood sums that in attendance were 32 delegates: four African representatives -one each from Ethiopia, Sierra Leone, Liberia, and Gold Coast, and a dozen from North America among who was W.E.B DuBois, 11 representatives from the West Indies and five from London, spearheaded by Williams in protest against the racial maltreatment of Africans in Rhodesia and South Africa. The conference according to Legum(1965) appealed to humanitarian organisations to use their influence and good office to douse the maltreatment of Africans and a memorial was addressed to Queen Victoria on the plight of the African man. The conference seeded ideas of Pan Africanism 
particularly through the intellectual engagement of the attendees who themselves had been victims of racial discriminations.

The role of independent indigenous churches according to Legum, especially the black African Methodist Episcopal Zion Church is important in the rise of Pan Africanism as these churches were established in resentment at discriminations in white churches, a desire for corporate ownership and through independence however limited, an advancement of status.

The outbreak of the $1^{\text {st }}$ world war 1914-1919 implied the conscription of African able bodied men to the armies of their respective metropolitan states, who fought side alongside European soldiers. The death of European soldiers on the battle field shattered the racial superiority claim of Europeans through the exposure of their weaknesses. After the war, this feeling of shattered arrogance lent support to the calls for the dismantling of discrimination and forceful occupation of the African land. In sustenance of the call for the unity of Africans, the $2^{\text {nd }}$ Pan African Conference was held in 1919 in Paris under the auspices of W.E.B DuBois who revived the movement that seemed moribund. During the war according to Contee (1972), DuBois believed that the changes and idealism of the war offered an opportunity for blacks to benefit from the ideals of democracy, anti-imperialism and anti-colonialism, especially as expressed in the 14 points. At the conference as presented by Contee (1972), resolutions were adopted which requested the gradual self government for Africans, the use of the League of Nations to supervise native rights, and blacks in Africa be accorded equal rights, liberty of conscience, the safeguarding of the right of Africans to their land and their health, labour and promotion of mass education for Africans and the right to participate in the government without a call for Africa's right to independence.

Not much change had been effected in the administration of the African peoples by Europeans at the $3^{\text {rd }}$ Pan African Congress of 1921 where renewed calls were made for the 1919 resolutions and the $4^{\text {th }}$ Conference of 1923 . The $5^{\text {th }}$ was held in 1927 still without significant changes in the administration of the African natives and was the last directly led by DuBois. The $2^{\text {nd }}$ World War marked a significant shift in the old and new Pan African movements. The young Africans who had trained in Diaspora were ready to take up leadership of the Pan African ideas. In 1944 as presented by Legum,, 13 active welfare students and political organisations came together to form the Pan African Federation and among its leaders were George Padmore, C.L.R James, Wallace Johnson, and Jomo Kenyatta.
The most important conference in the struggle against colonialism was the Manchester Conference of 1945 organised by the Pan African Federation. For the $1^{\text {st }}$ time, the conference was anchored by soon to be African young leaders that would take over administration in their respective territories and engage the colonial structures. Attendees included DuBois advanced in age, Kwameh Nkrumah, J. Annan, E.A Ayikunmi, Joe Appiah, Kurankyi Taylor all from Gold Coast, Chief H.O Daves, Magnus Williams who represented Dr Nnamdi Azikwe, Chief S.L.Akintola from Nigeria, from Kenya was Jomo Kenyatta, Wallace Johnson of Sierra Leone, Julius Nyerere of Tanganyika, Raphael Armattoe of Togo, Peter Abraham and Marko Hlubi of South Africa. The conference laid the foundation for the radical call for the autonomy and independence of the African states with the prescription of the exploration of all available options including violence to ensure the freedom of Africans and on the basis through which the achievement of a united Africa free from Western imperialism could be achieved. The conference demanded the drawing of positive plans for the development of the colonies. These seeds of radical approaches to the dismantling of colonialism were carried over to African territories by these fire brand nationalists who were influenced by the education received abroad radically intellectually engaged the colonialist governments, consequently contributing to the rise of political consciousness in Africa. The adoption of the Atlantic Charter of 1941 which granted rights of self determination to all peoples of the world further emphasised the call for autonomy and independence of the African states. The establishment of the United Nations, adoption of Resolution 1514 created platforms for the newly independent states such as India, Ghana to advocate for the independence of the still subjugated peoples.

The radical engagement of the colonial governments by African nationalist at the end of the $2^{\text {nd }}$ world war, the role of the United States through the instrumentality of the Atlantic Charter brought about some restructuring in the colonial administration such as the adoption of Richard Constitution of 1946 which secured the greater participation by Africans in the discussion of their own affairs, a right they had hitherto being denied, Lyttleton constitution of 1954 and the independence constitution of 1960 all which granted increased African participation in their affairs. However, these Nationalists did not participate in the actual drafting or approval of the constitution. Other changes witnessed in the colonies include the rapid increase in infrastructural developments such as the establishment of Cash Crop Boards, establishment of higher centres of 
learning for the training of the hands and minds such as the University College, Ibadan of 1948, and University College of Gold Coast also of 1948.

To Faluyi (1996), Industrial development assumed partnership efforts between the colonial and regional governments which had hitherto being limited in content and character, with varying responses. The colonial government in West Arica introduced different incentives to stimulate more foreign and domestic investments in the industrial sector such as the sponsoring of technical education, industrial researches, introduction of fiscal incentives such as tax holidays, enactment of import -duty relief of 1956, creation of industrial estates with facilities such as roads, water, electricity and the encouragement of profit plough back and room for profit repatriation. However, these industrialisation attempts were not oriented to the jumpstarting of the African economies into industrialised ones capable of producing capital goods rather than consumer goods, hence sustaining the dependence of African economies on the colonialist states.

The independence demanded and conceded to the African leaders was one that was superficial, and directed to the changing of administrative heads but not colonial economic substructures that ensured the sustained dependence, exploitation of Africa in International trades. The independence of African states save South Africa between 1957 and 1963 launched Africa from the $2^{\text {nd }}$ phase of slavery to the $3^{\text {rd }}$ aptly described by Julius, developmental and technical organisations such as the Organisation for African Unity now African Union, Economic Community of West African States, Mano River Union, the African and Mauritanian Common Organisation, West African Rice Development Association among others. All these organisations among others were aimed at proffering solutions to the development of the continent in its struggle against underdevelopment and true economic progress that would enable the young African states free themselves from economic dependence, develop and evolve consistently with assurance towards the rapid economic expectations of Africans. The fulfilment of these noble ambitions have been hampered by the hard and sad realities of colonial pasts and most importantly the insidious seed of discord sown by France in West Africa through the instrumentality of the Communate Economique De L'Afrique L'Ouest to frustrate the true unity and development of West Africa.

Worthy of emphasis is the fact that the early African leaders were determined to change the living conditions of their people, reorientation of governance structures and endeavour to keep law and order. In pursuit of their dreams for their respective countries, different political ideologies were propounded by the early African leaders such as Nkrumah's Socialist Approach, Sekou Toure's Democratic Dictatorship and socialist paths, Nyerere's advocacy for a one party state, Obafemi Awolowo's Democratic Socialism among others proved in some cases relevant to the true development of their various states while some ill managed ideologies were perfect recipes for disasters many African states plunged into soon after independence.

Kwameh Nkrumah's Socialist approach to the development of Africa drew its inspirations from his close working with C.L.R James, a West Indian Historian who both worked together in an underground organisation which espoused Kwameh to the formation of political parties, Marcus Garvey's United States of Africa and the 1945 Manchester conference. He perceived capitalism and socialism as two competing models of development. Capitalism to him is characterised by unhealthy competition and pursuit of supremacy, unfair distribution of National wealth; the cause and basis of the problems facing the new African nations. He opined that it was only the government that could initiate necessary actions that would spur development in any state, warning against the uncritical adoption of socialist models that created unequal opportunities leaving the people exploited. The mismanagement of his ideology soon handed Ghana to Military dictatorships.

Sekou Toure opined the development of African states was dependent on the adoption of democracy facilitated by a one party system which derives power from the people but dictatorial in nature to achieve an uninterrupted development in the interest of the people.

In Obafemi Awolowo's perspective, democratic socialism is a recipe for development of the African states which revolves around the African man (his dignity/pride and breaking obstacles to the achievement of his dignity). For the African man to fulfil providential purposes, the state must be sovereign, supreme and put in shape by the collaboration between the state leadership who derive their legitimacy from the people and the people supporting the development strides of the state. An ideal society that would inspire the achievement of potentials must provide or make provisions for the full employment for its citizens, guaranteed minimum wage, free education, good health service, rapid industrialisation, social insurance, infrastructural developments, among others.

Inspite of the great visions of the African leader for the construction of large dams, energy projects, national and intra African structures, economic development plans, they however did not succeed in the repositioning of their various economies to capital goods industrialised economies that would facilitate the true development of Africa but rather 
sustained the ties of their economy to the apron strings of the developed world.

\section{CHALLENGES TO PAN AFRICANISM}

The challenges facing Pan Africanist idea of Africa for Africans is a product of the machinations of two insidious enterprises of both internal factors and external realities. The external factors bedevilling the achievement of the upliftment of the African peoples are carefully woven and insidious to ensure the sustained dependence of African economies on the developed world, consequently rendering political administration puppets and stooges. These challenges have been more entrenched with the reality of globalisation. The Structural Adjustment programme prerequisites attached to the borrowing of money from Bretton woods institutions such as the International Monetary Fund, World Bank, Paris Club have posed major challenges to the advancement of the African man by methods of his own. These conditions involve the devaluation and further devaluation of local currencies, deindustrialisation, abolition of competition policies to protect local industries. The inability of local industries to compete favourably due to the absence of interventionist assistance and the reality of globalisation has forced indigenous industries out of operations.

Increasing technological gaps between Africa and the developed world is an external challenge to the prosperity of Africa. The notion of technology transfer from Global North to Africa has failed and in the process, the North has increased its technological monopoly through transnational or multinational corporations. Although transnational companies have played important roles in the economic development of Africa, they have however sustained the African dependence, and the damages caused the host are immensely greater than their benefits.

Debt burden of many African countries is fast rubbing of developmental strides. Due to the deficient budgets run by many African countries, they gullibly augment the deficit through external loans instead of cutting overhead cost of administration. In April 2019, according to Punch Newspaper (2019), Nigeria's debt stood at \#24.39trillion. It is to be noted that loans obtained from Bretton woods institutions and the newly found Chinese "love" are sometimes used to finance projects, looted or mismanaged. It is undeniable that these funds have been useful in the financing of projects that have brought some respite to the people such as road construction, provision of basic facilities such as water in some remote African communities. On the other hand due to the devaluation of local currencies, African states pay more in debt servicing, consequently denying her of developments.
The encouragement of Africa's dependency on monocursal economies by the developed world has robbed African countries of diversification initiatives. Many African economies are monocursal either based on the production of unprocessed food and cash crops or petro dollar economies as run by Nigeria. The Nigerian economy before petrol dollar was based on agriculture, though in its unrefined states, provided huge revenues to the actors in the trade. The shift of the Nigerian economy to petrol dollar at the expense of the development of other sectors capable of jump starting the Nigerian economy into capital goods industrialisation has subjected her economy to external manipulations.

The internal realities of the African states have allowed for the easy manipulation from external realities. The unhealthy competition among African states which emanates from fear of domination by big countries over smaller nations has hampered cooperation attempts among African countries for the development of the continent. In West Africa, the fear of Nigerian domination of francophone West African states reflects in the absence of commitment to the achievement of ECOWAS, the main economic cooperation instrument of West Africa. Through France's sown contradictory interest through the CEAO, it has undermined the true unity, a necessary requirement for development and upsetting of colonial economic substructures.

The docility of many African citizens have given free hands to the mismanagement of the Africa's common wealth and the irresponsible dispositions of the government who are expected to hold power in trust. Flowing from the docility of many citizens of African states, many leaders are not held accountable for their actions and inactions partly due to insufficient education, ethnic and or religious inclinations of the populace, the power of money and law enforcement brigandage. The docility have also been met by absence of leaders' political will and commitment who often see themselves as overlords rather than servants of the people. The forceful engagement of the government by citizens of some African countries such as The Gambia, Liberia, Algeria, Cote D'Ivoire among others have led yielded fairly positive results in the changing of the living standards of their people.

Corruption has deeply eaten into the African social fabric and has robbed Africa collectively of true development. Many governments run state administrations like personal heritages with striking great abuse office. Mobutu Sesesenko of Zaire, now Congo, Samuel Do of Liberia, Abacha of Nigeria readily come to mind as examples of destructive management. The mismanagement and authoritarian rule have provoked persistent crisis 
and conflicts across Africa which includes civil wars, ethnic clashes all of which entail the waste of scarce resources. The resulting economic and social depression, mass relocation, massive brain drains and political instability have made the development of the continent virtually impossible.

The inability of many African leaders to address developmental issues is a clog to the wheels of Africa's development. The absences of protection of local industries from foreign competition in Nigeria have forced many to oblivion. The increasing difficulty encountered by small businesses to obtain loans from commercial banks and the conditions attached to micro finance loans, coupled with the unfriendly business environment have watered down and discouraged ingenious business ideas and potentials. The perception of Africans to African branded goods has also done great harm to producing local industries. Many indigenous products are boycotted for big names, promoting European patronages at the expense of local ingenuity. The infamous Nigerian Aba goods readily come to mind.

The deliberate base of many economies on monocursal structures due to lack of ingenuity and greed have hampered the expanse development of other potential sectors such as mining, steel manufacturing, etc. in Nigeria in the 1960s, all the regions were famous for their produces such Western Nigerian Cocoa and Kolanut, Northern Groundnut pyramids, South Eastern palm produce, South South faunas and floras. Contemporaneously, Nigeria's wealth is dependent on the milking of South South's 'thin cow'.

\section{PAN AFRICANISM CHALLENGES: PANACEA APPRAISAL}

In the surmounting of the challenges that have hampered the unity and true development of the African people, several panaceas have been introduced and adopted. They include establishment of anti graft agencies, emergence of public private agencies, establishment of empowerment initiatives, trial and prosecution of reckless use of power against humanity, civil uprisings and revolt among others.

The establishment of anti graft agencies in many African states have fairly put a ban on the flagrant public funds mismanagement and promoted transparency particularly within government quarters and outside government domains. Examples of these anti graft agencies include Egypt's Administrative Control Authority, Kenya's Ethics and Anti-Corruption Commission, Liberia's Anti- Corruption Commission, South Africa's National-Anti-Corruption Forum, Nigeria's Economic and Financial Crimes Commission(EFCC) and the Independent Corrupt Practices Commission, Burundi's Anti-Corruption and Economic Malpractice Observatory among others. In assessing the Nigerian fight against financial corruption the EFCC has recorded fair level of success such as the trial of convicted looters such as Chief Bode George, Former Inspector General Tafa Balogun, former Plateau state Governor and senator Joshua Dariye , recovery of $\$ 2.9$ million in cash from a home belonging to the former group Managing Director of the Nigerian National Petroleum Corporation ( NNPC) Andrew Yakubu in Sabon Tasha, Kaduna, \#450 million from an abandoned shop in the Nigerian Air Force complex in Victoria Island Lagos, \$43.5 million, \#23.2 million at no 16, Osborne road, Ikoyi, Lagos. In May 2018, as stated by the Economic and Financial Crimes Commission (2019) the commission recovered over \#523 billion, \$52million and 122.89 million pounds among other achievements. A critical appraisal of this agency depicts its deep politicised has become a potent tool in the harassment of political opponents within the Nigerian political space.

The failure and the inability of the various governments to institute far reaching changes in the society have inspired public private partnership. According to Muhammed (2017), it is an initiative directed towards the provision of public infrastructures that cannot be easily provided by the government alone because of paucity of funds. Projects such as Lagos Light Rail Transit System, Akute Power Plant Project among others as examples. Governments unaccountability, poor maintenance culture is fast undermining the efficacy of this initiative.

The establishment of empowerment initiatives have ameliorated the difficulty experienced by African entrepreneurs in securing funds for start-ups and advancement. Many nongovernmental organisations have risen to the challenge of contributing their 1 quotas to the development of local businesses. Worthy of complementation is the Tony Elumelu Foundation championing entrepreneurship and entrepreneurs across the continent through empowerment that aims at positioning Africa's private sector for the economic development of the continent.

\section{CONCLUSION}

The African continent was a one human entity before the cancerous contact with the Europeans that changed its history forever. The docility, gullibility and cooperation of Africans with Europeans in the sale of their fellow men sowed the seed for the subsequent maltreatment, discrimination, lost and deprived dignity and persecution of the black man. The obnoxious changed the perception nof the African continent which had hitherto been the lifeline of other 
continents to such that was inferior and needed to be civilised in the interest of the Africans and mankind.

The racial discriminatory treatment of blacks laid the basis for the infamous political, racial and intellectual movement aimed at challenging the inferiority status ascribed to the African man, showcasing Africa's glorious past and a challenging call to Africans to unite on the basis through which the dislodgement of alien domination was possible.

The spirit of Pan Africanism was sustained by early African nationalists but however short lived. Though attempts have been made to resuscitate the spirit of the African unity through political, economic, developmental and technological organisations, Africa still suffers from certain forms of economic integration, in particularly those resulting from contradictory interest among industrialised countries. If Africa will truly be a continent of Africa for Africans, a more deliberate and conscious efforts must be made by African countries to decisively fight off colonial strings that have sustained the fair integration of the African economy in the international trade and tied its development to the apron strings of the developed countries.

\section{REFERENCE}

1. Anene, J. (1966). Slavery and Slave Trade. Africa in the Nineteen and Twentieth Centuries. J.C. Anene and Godfrey Brown, Eds.Ibadan: Ibadan University Press, (pp 92-109).

2. Apiah,A. (2012). Pan Africanism Africana: The Encyclopaedia of the African and African American Experience, $2^{\text {nd }}$ Edition. K.A Appiah and H.L Gates. Eds. Oxford African American Studies Centre. Information retrieved June 5, 2019 from

http://www.oxfordaasc.com/article/opr/t00 02/e3057.

3. Contee, C.(1972). DuBois, the NAACP and the Pan African Congress of 1919. The Journal of Negro History. Vol.57, (p1).

4. Curtin, P. (1969). The Atlantic Slave Trade: A Census. Madison: University of Wisconsin Press, (p 268).

5. Davidson, B. (1980). Before the Trade Began. The African Slave Trade. Boston: Atlantic Monthly Press,(pp 26-27).

6. Duodu, C. (2011). Edward Wilmot Blyden, Grandfather of African Liberation. The Patriotic Vanguard

7. Economic and Financial Crimes Commission. (2019). Whistle blowing :
EFCC recovers \#527bn, \$53m, 123 pounds-Magu. Retrieved April 27, 2019 from

www.efccnigeria.org/efcc/news/3001whistle-blowing-efcc-recovers-\#527bn\$53m-123-magu.

8. Esedebe,P.(1970). Origins and Meaning of Pan-Africanism. Presence Africaine, vol.73, Nouvelle Serie

9. Faluyi, K. (1996). Industrialisation Under Colonial Rule, Economic History of West Africa. G.O. Ogunremi and E.K. Faluyi. Eds. Ibadan: Rex Charles Publication, ( $p$ 232).

10. Hobson, J.(1975). Imperialism: A Study. New York: Gordon Press, (pp 28-40).

11. Legum,C. (1965). Pan Africanism: A Short Political Guide. London: Frederick.A.Praeger,(p15).

12. Lenin, V. (1939). Imperialism, the highest stage of Capitalism; A Popular Outline, New York: International Publishers, (p 59).

13. Opening address of President Ahmed Sekou Toure ,(1982). ECOWAS $2^{\text {nd }}$ Conference, (p 12).

14. Pan Africanism Africana. The Encyclopedia of the African and African American Experience, $2^{\text {nd }}$ Edition, ( $\left.\mathrm{p} 4\right)$.

15. Sherwood, M.(2012).Pan-African Conferences, 1900-1953:What did PanAfricanism Mean,The Journal of Pan African Studies, vol.4, (p 10).

16. Amaefule, E. Punch Newspaper.(April 5, 2019). Nigeria's debt Hits \#24.39tn rises by N2.66tn in one year.. Retrieved June 9, 2019 from https://www.google.com/amp/s/punchng.c om/nigerias-debt-hits-n24-39tn.rises-byn2-66tn-in-one-year/amp/

17. Punch Newspaper. Mohammed, A, (October 6, 2017). Is Public Private Partnership Initiative Working in Nigeria. Retrieved June 9, 2019 from https://www.google.com/amp/s/punchng.c om/is-public-private-partnershipinitiative-working-in-nigeria/amp/

18. Rodney,W. (1972). How Europe Underdeveloped Africa. London: BogleL'Ouverture Publications, (p 40).

19. The Tony Elumelu Foundation; The Leading Philanthropy in Africa Championing Entrepreneurship. Retrieved June 9, 2019 from https://www.tonyelumelufoundation.org. 